\title{
BMJ Open The smoking habit of a close friend or family member-how deep is the impact? A cross-sectional study
}

\author{
Antti J Saari, ${ }^{1,2}$ Jukka Kentala, ${ }^{3}$ Kari J Mattila ${ }^{1,4}$
}

To cite: Saari AJ, Kentala J, Mattila KJ. The smoking habit of a close friend or family member-how deep is the impact? A cross-sectional study. BMJ Open 2014;4: e003218. doi:10.1136/ bmjopen-2013-003218

- Prepublication history for this paper is available online. To view these files please visit the journal online (http://dx.doi.org/10.1136/ bmjopen-2013-003218).

Received 13 May 2013 Revised 16 August 2013 Accepted 9 October 2013
CrossMark

For numbered affiliations see end of article.

Correspondence to Dr Antti J Saari; antti.j.saari@uta.fi

\section{ABSTRACT}

Objectives: To assess the risk of becoming a smoker in adulthood associated with parental smoking as well as the smoking of siblings and close friends.

Design: A cross-sectional study.

Setting: 4 oral healthcare centres in Finland and a follow-up.

Participants: An age cohort born in $1979(n=2586)$ and living in four Finnish towns. Of those reached by the 2008 follow-up, $46.9 \%(n=1020)$ responded.

Primary and secondary outcome measures: Smoking behaviour at the age of 29. Smoking behaviour at the age of 13 and smoking behaviour of family members and close friends.

Results: Smoking of a current close friend was strongly associated with participants' own smoking (OR 5.6, 95\% Cl 3.6 to 8.8). The smoking of a close friend during schooldays was similarly associated (OR $2.9,95 \% \mathrm{Cl} 1.8$ to 4.5$)$. Smoking among men was associated with the smoking behaviour of mothers and siblings while that among females was not.

Conclusions: The impact of a smoker as a close friend is greater than that of a smoking parent or sibling in school age when it comes to smoking behaviour in adulthood. This should be taken into consideration when attempting to prevent smoking initiation or continuation.

Trial registration: At clinicaltrials.gov (NCT01348646).

\section{INTRODUCTION}

Smoking is an unhealthy and lethal habit. There is a linear association between the duration and heaviness of smoking and its negative impact on an individual's health. A persistent smoking habit greatly increases the risk of premature death. ${ }^{1}$ If smoking disappeared from this world, millions of lives would be saved. $^{2}$

The development of nicotine dependence and smoking habit is linked to social influence from family and friends. ${ }^{3-6}$ Children who are exposed to smoking at home are more likely to experiment with smoking. ${ }^{7} 8$ A smoking parent makes an adolescent more

\section{Strengths and limitations of this study}

- All the social influences on smoking were studied in the same population.

- A limitation is that the smoking behaviour of close friends and family members on schooldays was measured retrospectively.

- Response rate can be considered unsatisfying.

positively disposed to smoking. ${ }^{9}$ Smoking siblings also increase the risk of regular smoking. ${ }^{10}$ Similar smoking patterns among family members can be partly explained through shared genes. ${ }^{11}$ Adolescent cessation programmes including a parental approach have reported good results. ${ }^{12}$ This emphasises the importance of family influences in adolescent smoking.

The smoking behaviour of peers has a great influence on adolescents' own smoking habits. ${ }^{13}$ The influence of smoking peers seems to be greater than that of smoking parents when considering the likelihood of an adolescent starting to smoke ${ }^{14-16}$ or continuing the habit from adolescence to adulthood. ${ }^{17}$ There is also evidence that the increased risk of continuing smoking caused by a smoking peer is comparable to that caused by smoking parents. ${ }^{18}$ A male best friend who smokes seems to have a greater effect on smoking initiation than a female best friend who smokes. ${ }^{19}$ Genes seem to influence the choice of friends and thus indirectly influence adolescent smoking. ${ }^{20}$

A variety of theories have been proposed regarding the association of social influence and smoking behaviour. Perceived influence theories try to explain this through adolescents' perceptions of their peers' smoking behaviour. In external influence theories, the smoking behaviour of peers has a direct influence on adolescent smoking. Group-level theories examine how differences in gender, race and subculture influence the relationships and thus smoking behaviour. ${ }^{21}$ 
Approximately one in four adult men and one in five adult women in Finland are regular smokers. ${ }^{22}$ In Finland, the smoking trends have been slightly diminishing in recent years. Nevertheless, the smoking rate among young adult women remains a significant issue and recent global evidence shows a rising trend in the smoking rates among women. ${ }^{23} 24$

The aim of this study was to ascertain the risk of becoming an adult smoker associated with parental smoking as well as the smoking of siblings and close friends. Although the importance of social influences in smoking behaviour is widely acknowledged, we wanted to compare the strength of these influences.

\section{MATERIALS AND METHODS}

The cohort consisted of all participants born in 1979 and living in 1992 in the Finnish towns of Vaasa, Pietarsaari, Kokkola or Seinäjoki ( $n=2582$; figure 1). ${ }^{25}$ These towns are all located in a province with very similar school conditions. Of the age cohort, $99.1 \%$ participated in a dental check-up in 1992. During the check-up, they responded to a questionnaire and some

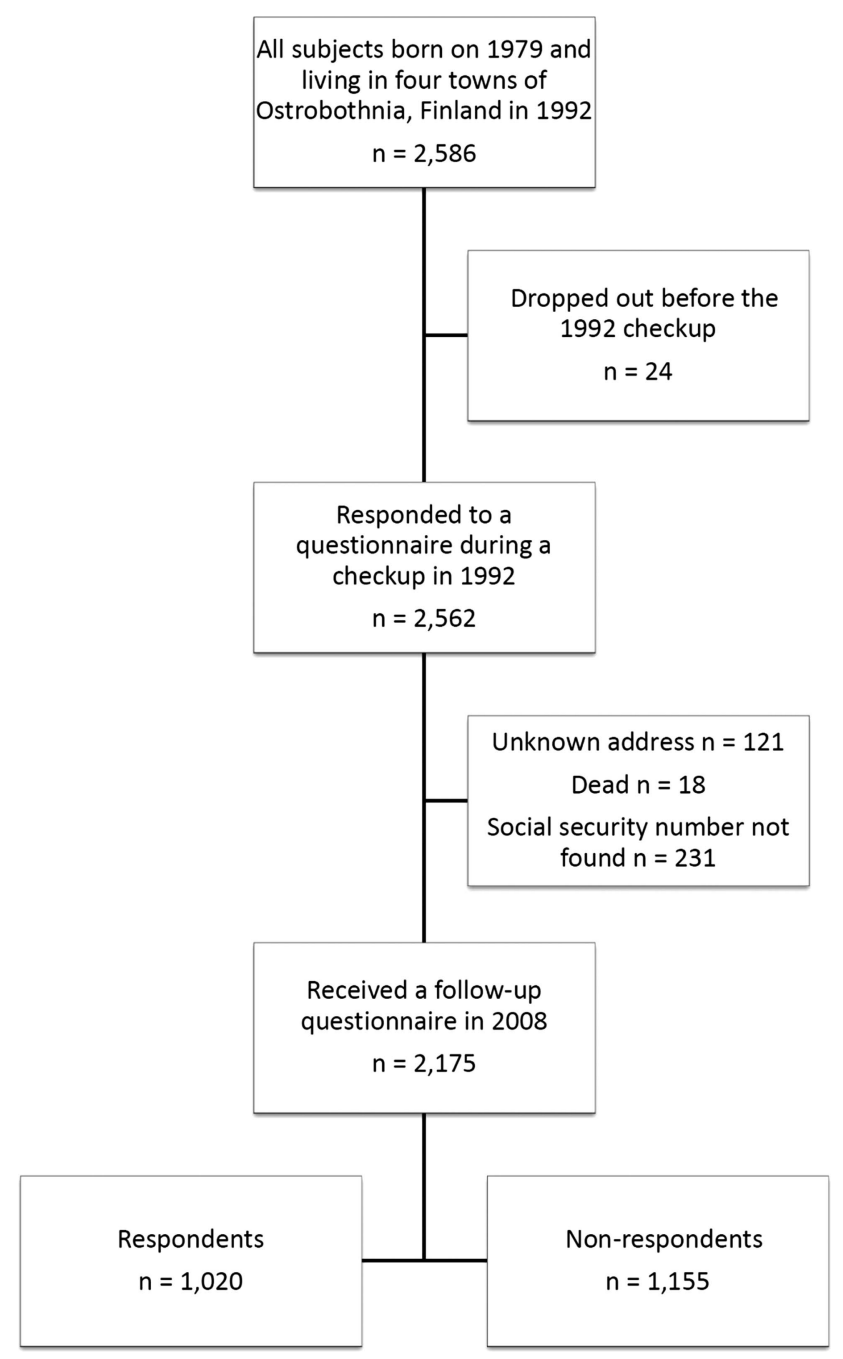

Figure 1 Flow-chart of the evolution of the cohort. oral questions. Their current smoking behaviour and their intentions to experiment with smoking were elicited. The smoking rate in this population was $5.7 \%$ $(n=148)$ at the beginning of the study and $19.4 \%$ $(n=304)$ at the time of the final examination in $1994 .^{25}$ Half the population received annual brief tobacco interventions during the period 1992-1995. These interventions had no long-term effect on their smoking. ${ }^{26}$

A questionnaire was sent to the available cohort $(n=2175)$ in 2008 to addresses obtained from the Population Register Centre (figure 1). The response rate was $46.9 \%(n=1020)$. Respondents were classified as smokers and non-smokers according to their responses to the question 'Do you smoke?' (no/yes).

In the questionnaire, the respondents were asked to look back at their smoking exposure in their schooldays. Our study was based on perceived influence theory and thus the respondent's own perception of his/her influences was of interest. The respondents answering 'yes' to the question 'When you were of school age, did your father smoke?' (no/yes/can't say) were deemed to have had a smoking father in their schooldays. The same pattern was repeated with similar questions about the smoking habits of mother, brother, sister and close friend during respondents' schooldays. Those without a brother (or a sister) were treated as missing data according to the question on smoking behaviour of their brother (or sister). The respondents answering 'yes' to the question 'Does your close friend smoke?' were deemed to currently have a smoking best friend.

We also measured some potential confounders for smoking, namely marital status, level of education and selfperceived health. Marital status was elicited as single/ married/cohabiting/remarried/divorced/widowed. Single, divorced and widowed respondents were classified as single, while married, remarried and cohabiting respondents were classified as married or cohabiting. Education was classified as higher education if the respondent had a polytechnic or university degree. All other education was classified as lower education. Respondents' self-perceived health was also elicited as very good/good/average/poor/very poor/can't say. The responses were reclassified as very good/not very good, where all answers other than very good were classified as not very good.

A cover letter describing the purpose and methodology of the study and a consent form were enclosed with the questionnaires. Only completed questionnaires returned with a signed consent form were used as data.

\section{Analysis of non-response}

We used the relevant measurements from the 1992 study to compare respondents with the non-respondents (table 1). Among the respondents, there were significantly more women and those who had not tried smoking by the age of 13. There were no differences between respondents and non-respondents according to smoking behaviour at the age of 13, willingness to try smoking (among those who were non-smokers at the age of 13) or smoking behaviour of parents. 
Table 1 Comparison of the respondents and non-respondents to the 2008 follow-up according the baseline measurements from the 1992 questionnaire

\begin{tabular}{|c|c|c|c|c|c|}
\hline & \multicolumn{2}{|c|}{ Respondents ( $n=1020)$} & \multicolumn{2}{|c|}{ Non-respondents $(n=1155)$} & \multirow[b]{2}{*}{ p Value } \\
\hline & $\bar{n}$ & Percentage of group & $\overline{\mathbf{N}}$ & Percentage of group & \\
\hline Smoking at age 13 & & & & & 0.097 \\
\hline No & 972 & 95.3 & 1441 & 93.7 & \\
\hline Yes & 48 & 4.7 & 97 & 6.3 & \\
\hline Gender & & & & & $<0.001$ \\
\hline Female & 605 & 59.3 & 646 & 41.9 & \\
\hline Male & 415 & 40.7 & 895 & 58.1 & \\
\hline Experimentations at age 13 & & & & & $<0.001$ \\
\hline Had not tried smoking & 585 & 60.4 & 727 & 50.9 & \\
\hline Had tried smoking & 383 & 39.6 & 702 & 49.1 & \\
\hline Attitude at age 13 & & & & & 0.83 \\
\hline Not willing to try smoking & 661 & 94.3 & 916 & 93.9 & \\
\hline Willing to try smoking & 40 & 5.7 & 59 & 6.1 & \\
\hline Parent smoking & & & & & 0.18 \\
\hline No & 584 & 60.3 & 821 & 57.5 & \\
\hline Yes & 384 & 39.7 & 606 & 42.5 & \\
\hline
\end{tabular}

\section{Statistical analysis}

We used IBM SPSS V.20.0 to conduct the statistical analyses. Binary logistic regression was used with 95\% CI and the depending variable was smoking (yes/no) at the age of 29. Two binary outcome measures were compared with $\chi^{2}$ test. Missing data for a measurement was treated as non-response for that measure. Those who did not respond in the 2008 follow-up were treated as missing data for all measurements excluding those used for analysis of non-response (see below).

\section{RESULTS}

Of all respondents, $16.9 \% \quad(n=168)$ were smokers in 2008 (table 2). Smoking rates were $14.4 \% \quad(n=86)$ among women and $20.4 \%(n=82)$ among men $(p<0.05)$. The majority of respondents were married or cohabiting, had higher education and perceived their health to be very good (table 2).

The majority of smokers had lower education while only less than one-third of non-smokers had lower education (table 3). This difference was statistically significant. A statistically significant difference was found between smokers' and non-smokers' self-perceived state of health. One in ten non-smokers but one in four smokers reported their self-perceived health to be other than very good (table 3 ). There were also statistically significantly more women among non-smokers (table 3).

There was a strong connection with the smoking behaviour of the current close friend. Among those men who currently had a smoking close friend it was 7.1 (95\% CI 3.6 to 14.0$)$ times more likely that they, too, were smokers. This connection was slightly weaker but still significant among women (OR 4.7, 95\% CI 2.5 to 8.6).

Table 2 Comparison of the cohort characteristics in the 1992 study and in the 2008 follow-up

\begin{tabular}{|c|c|c|c|c|}
\hline & \multicolumn{2}{|c|}{1992 initial study (mean age 13) } & \multicolumn{2}{|c|}{2008 follow-up (mean age 29) } \\
\hline & $\overline{\mathbf{n}}$ & Percentage of group & $\bar{n}$ & Percentage of group \\
\hline \multicolumn{5}{|l|}{ Gender } \\
\hline Female & 1251 & 48.8 & 596 & 59.8 \\
\hline Male & 1310 & 51.2 & 401 & 40.2 \\
\hline \multicolumn{5}{|l|}{ Smoking behaviour } \\
\hline Smoker & 145 & 5.7 & 168 & 16.9 \\
\hline Non-smoker & 2413 & 94.3 & 829 & 83.1 \\
\hline \multicolumn{5}{|l|}{ Marital status } \\
\hline Single & - & - & 221 & 34.5 \\
\hline Married or cohabiting & - & - & 775 & 65.5 \\
\hline \multicolumn{5}{|l|}{ Education } \\
\hline Lower & - & - & 338 & 34.2 \\
\hline Higher & - & - & 651 & 65.8 \\
\hline \multicolumn{5}{|l|}{ Self-perceived health } \\
\hline Very good & - & - & 866 & 86.9 \\
\hline Not very good & - & - & 130 & 13.1 \\
\hline
\end{tabular}


Table 3 Comparison of smokers and non-smokers according to the measured potential confounders

\begin{tabular}{|c|c|c|c|c|c|}
\hline & \multicolumn{2}{|c|}{ Smokers $(n=168)$} & \multicolumn{2}{|c|}{ Non-smokers $(n=829)$} & \multirow[b]{2}{*}{ p Value } \\
\hline & $\mathrm{n}$ & Percentage of group & $\mathrm{n}$ & Percentage of group & \\
\hline Gender & & & & & 0.016 \\
\hline Female & 86 & 51.2 & 510 & 61.5 & \\
\hline Male & 82 & 48.8 & 319 & 38.5 & \\
\hline Marital status & & & & & 0.155 \\
\hline Single & 44 & 26.3 & 177 & 21.4 & \\
\hline Married or cohabiting & 123 & 73.7 & 652 & 78.6 & \\
\hline Education & & & & & $<0.001$ \\
\hline Lower & 94 & 56.6 & 244 & 29.6 & \\
\hline Higher & 72 & 43.4 & 579 & 70.4 & \\
\hline Self-perceived health & & & & & $<0.001$ \\
\hline Very good & 121 & 72.0 & 745 & 90.0 & \\
\hline Not very good & 47 & 28.0 & 83 & 10.0 & \\
\hline
\end{tabular}

Among women having a smoker as a close friend in school was connected with more than five times greater likelihood of being a smoker in adulthood (OR 5.1, 95\% CI 2.6 to 10.0$)$. No connection with smoking behaviour of close friend in school was observed in men. Smoking of mother, brother or sister when the participant was of school age increased the likelihood of being a smoker more than twofold among men, but the smoking habit of any family member had no effect among women. The smoking behaviour of father when the participant was of school age did not have a connection with the participant's smoking behaviour in adulthood.

In the adjusted model, we combined all the family members and best friends (current and in schooldays) with the measured confounders into a multivariate logistic regression (table 4 ). The impact of friends (current or in schooldays) persisted in the adjusted model while that of all the family members disappeared (table 4). Self-perceived health and marital status had an independent connection with smoking behaviour in adulthood, but the strength of these connections was less than that of the influence of close friends.

\section{DISCUSSION}

This study ascertained the gravity of the implications of having a smoking parent, sibling or friend. The greatest impact on adult smoking comes from the current close friend. We see this as a result of orientation-we want a friend who reminds us of ourselves. We think that people who smoke see smoking as a part of their selfimage and thus tend to have friends who also are smokers. Friends who smoke increase the likelihood of their friends continuing smoking. ${ }^{27}$

Earlier studies have focused mainly on groups like families, siblings or friends in general. We studied the influences of all the immediate family members (mother, father, sister and brother) and close friends in schooldays and in adulthood, separately and from the same cohort. A recently published Finnish study concurs with our results about the importance of best friend's influence over family member influences. ${ }^{28}$ This increases the reliability of our results. Our population is representative of Finns and our results can be generalised to comparable populations.

In an older American study, it was concluded that male best friends have a greater influence on smoking initiation. ${ }^{19}$ In our results men seemed to be less influenced by their best friends in school than were women. However, our interest was more in the persistence of smoking to adulthood and from this type of data the direction of causality cannot be determined. The gender differences could be explained by differences in social networking between men and women. ${ }^{29}$ Girls tend to form intense bilateral friendships while boys' social networks are in large packs with looser bonds of friendship. We still do not know who influences whom when it comes to transferring smoking behaviour from one friend to another.

Innumerable studies have considered methods of smoking cessation involving medical consultations. We want to emphasise that smoking prevention must not be seen as something only doctors can do. The onset of a lifelong smoking habit is usually in adolescence. ${ }^{30}$ One can also say that if a person does not start to smoke in adolescence, that person is unlikely to start to smoke at all. The culture of emulation among growing adolescents, routine cessation programmes for expectant parents, tobacco price policies, tobacco advertisement restrictions and impeding access to tobacco products are something we really need to take seriously if we want to quell the smoking epidemic. Only a very small part of this work can be performed in the doctor's consultation room, but it is important that the work that doctors do with their patients is consonant with the consistent antismoking strategies. The results of this study demonstrate the great importance of close friends' influence on smoking. This should be noted as an advantage for planning antismoking actions addressing social influences. 
Table 4 Logistic regression analysis of all respondents according to their own smoking behaviour and the smoking behaviour of their family members and friends with the potential confounding factors

\begin{tabular}{|c|c|c|c|}
\hline & & $\begin{array}{l}\text { OR for being } \\
\text { smoker }(95 \% \mathrm{CI})\end{array}$ & p Value \\
\hline \multicolumn{4}{|l|}{ Close friend } \\
\hline \multirow[t]{3}{*}{ In current life } & & & $<0.001$ \\
\hline & Non-smoker & 1 & \\
\hline & Smoker & 5.0 (3.1 to 7.8$)$ & \\
\hline \multirow[t]{3}{*}{ In school } & & & $<0.001$ \\
\hline & Non-smoker & 1 & \\
\hline & Smoker & 3.1 (1.9 to 5.0 ) & \\
\hline \multirow[t]{3}{*}{ Mother } & & & 0.06 \\
\hline & Non-smoker & 1 & \\
\hline & Smoker & 1.7 (1.0 to 2.8$)$ & \\
\hline \multirow[t]{3}{*}{ Father } & & & 0.7 \\
\hline & Non-smoker & 1 & \\
\hline & Smoker & $1.1(0.7$ to 1.8$)$ & \\
\hline \multirow[t]{3}{*}{ Sister } & & & 0.8 \\
\hline & Non-smoker & 1 & \\
\hline & Smoker & 1.7 (0.9 to 3.0$)$ & \\
\hline \multirow[t]{3}{*}{ Brother } & & & 0.9 \\
\hline & Non-smoker & 1 & \\
\hline & Smoker & 1.6 (0.9 to 2.7$)$ & \\
\hline \multirow[t]{3}{*}{ Gender } & & & 0.14 \\
\hline & Female & 1 & \\
\hline & Male & 1.4 (0.9 to 2.2$)$ & \\
\hline \multirow[t]{3}{*}{ Marital status } & & & 0.012 \\
\hline & Married or cohabiting & 1 & \\
\hline & Single & 2.0 (1.2 to 3.3$)$ & \\
\hline \multirow[t]{3}{*}{ Education } & & & 0.08 \\
\hline & Higher & 1 & \\
\hline & Lower & 1.5 (1.0 to 2.4$)$ & \\
\hline \multirow[t]{3}{*}{ Self-perceived health } & & & 0.008 \\
\hline & Very good & 1 & \\
\hline & Not very good & $2.3(1.2$ to 4.1$)$ & \\
\hline
\end{tabular}

\section{Limitations}

The response rate $(46.9 \%)$ was low but satisfactory since we had no incentive or other external motivator to increase the inclination to respond. We concede that selection bias had an effect on our results: in 1992, almost one of two respondents was women, but in the 2008 follow-up, three of five respondents were women. The smoking rates among our study population were lower than those reported by population studies in Finland, ${ }^{22}$ and this is likely to be caused by response bias. Most respondents had higher education and very good self-perceived health. Thus, it is likely that many of those with health problems and lower education did not respond to the 2008 follow-up. This affects our results; it is likely that there were more adult smokers among the non-respondents.

We did not elicit parental occupation, parental income or parental education. Thus, these potential confounders may have affected our results. We did not measure the smoking behaviour of the respondents' schooldays close friends prospectively and thus it is possible that the close friend was recalled incorrectly.

A weakness of our protocol is that the smoking behaviour of parents, siblings and close friends was determined by only one question. Thus, we do not know about the heaviness of their smoking, periods of abstinence and if their possible smoking was clearly visible to the participant. These are, however, unlikely to have caused any bias in our results since we were interested in whether the participants felt they had had smokers among their family or friends.

\section{CONCLUSIONS}

The smoking behaviour of a close friend is significantly associated with participants' own smoking behaviour in adulthood. The impact of this association is much greater than the impact of smoking family members. This should be taken into consideration in attempts to prevent smoking initiation or continuation. 
Author affiliations

${ }^{1}$ Department of General Practice, University of Tampere, Tampere, Finland

${ }^{2}$ JYTA, Tunkkari Health Care Center, Veteli, Finland

${ }^{3}$ Social and Health Services, Vaasa, Finland

${ }^{4}$ Center of General Practice, Pirkanmaa Hospital District, Tampere, Finland

Contributors AJS designed the study, gathered and processed data and wrote the article. JK designed the study and wrote the article. KJM supervised and designed the study, processed data and wrote the article. All authors contributed to and have approved the final version of the manuscript.

Funding This study was financially supported by the Department of General Practice, Medical School, University of Tampere, Finland.

Competing interests None.

Patient consent Obtained.

Ethics approval The Ethics Committee of the Pirkanmaa Hospital District, Finland approved the study protocol (R08017).

Provenance and peer review Not commissioned; externally peer reviewed.

Data sharing statement No additional data are available.

Open Access This is an Open Access article distributed in accordance with the Creative Commons Attribution Non Commercial (CC BY-NC 3.0) license, which permits others to distribute, remix, adapt, build upon this work noncommercially, and license their derivative works on different terms, provided the original work is properly cited and the use is non-commercial. See: http:// creativecommons.org/licenses/by-nc/3.0/

\section{REFERENCES}

1. Doll R, Peto R, Boreham J, et al. Mortality in relation to smoking: 50 years' observations on male British doctors. BMJ 2004;328:1519.

2. Moolgavkar SH, Holford TR, Levy DT, et al. Impact of reduced tobacco smoking on lung cancer mortality in the United States during 1975-2000. J Natl Cancer Inst 2012;104:541-8.

3. Tyas SL, Pederson LL. Psychosocial factors related to adolescent smoking: a critical review of the literature. Tob Control 1998;7:409-20.

4. Lerman C, Berrettini W. Elucidating the role of genetic factors in smoking behavior and nicotine dependence. Am J Med Genet $B$ Neuropsychiatr Genet 2003;118:48-54.

5. Okoli CT, Richardson CG, Ratner PA, et al. Non-smoking youths' 'perceived' addiction to tobacco is associated with their susceptibility to future smoking. Addict Behav 2009;34:1010-16.

6. deVries $\mathrm{H}$, Candel M, Engels R, et al. Challenges to the peer influence paradigm: results for 12-13 year olds from six European countries from the European Smoking Prevention Framework Approach study. Tob Control 2006;15:83-9.

7. Farkas AJ, Gilpin EA, White MM, et al. Association between household and workplace smoking restrictions and adolescent smoking. JAMA 2000;284:717-22.

8. Barman SK, Pulkkinen L, Kaprio J, et al. Inattentiveness, parental smoking and adolescent smoking initiation. Addiction 2004;99:1049-61.

9. Wilkinson AV, Shete S, Prokhorov AV. The moderating role of parental smoking on their children's attitudes toward smoking among a predominantly minority sample: a cross-sectional analysis. Subst Abuse Treat Prev Policy 2008;14:18.
10. Sasco AJ, Merrill RM, Benhaim-Luzon V, et al. Trends in tobacco smoking among adolescents in Lyon, France. Eur $J$ Cancer 2003;39:496-504.

11. Vink JM, Willemsen G, Engels RC, et al. Smoking status of parents, siblings and friends: predictors of regular smoking? Findings from a longitudinal twin-family study. Twin Res 2003;6:209-17.

12. Tingen MS, Waller JL, Smith TM, et al. Tobacco prevention in children and cessation in family members. J Am Acad Nurse Pract 2006;18:169-79.

13. Kobus K. Peers and adolescent smoking. Addiction 2003;98(Supp 1):37-55.

14. Flay BR, Hu FB, Siddiqui O, et al. Differential influence of parental smoking and friends' smoking on adolescent initiation and escalation of smoking. J Health Soc Behav 1994;35:248-65.

15. Bricker JB, Peterson AV Jr, Andersen MR, et al. Childhood friends who smoke: do they influence adolescents to make smoking transitions? Addict Behav 2006;31:889-900.

16. Kemppainen U, Tossavainen $\mathrm{K}$, Vartiainen $\mathrm{E}$, et al. Environmental factors as predictors of smoking among ninth-grade adolescents in Pitkaranta (Russian Karelia) and in eastern Finland. Res Nurs Health 2006;29:543-55.

17. West $P$, Sweeting $H$, Ecob R. Family and friends' influences on the uptake of regular smoking from mid-adolescence to early adulthood. Addiction 1999;94:1397-411.

18. de Vries $\mathrm{H}$, Engels $\mathrm{R}$, Kremers $\mathrm{S}$, et al. Parents' and friends' smoking status as predictors of smoking onset: findings from six European countries. Health Educ Res 2003;18:627-36.

19. Distefan JM, Gilpin EA, Choi WS, et al. Parental influences predict adolescent smoking in the United States, 1989-1993. J Adolesc Health 1998;22:466-74.

20. White VM, Hopper JL, Wearing AJ, et al. The role of genes in tobacco smoking during adolescence and young adulthood: a multivariate behavior genetic investigation. Addiction 2003;98:1087-100

21. Hoffman BR, Sussman S, Unger JB, et al. Peer influences on adolescent cigarette smoking: a theoretical review of the literature. Subst Use Misuse 2006;41:103-55.

22. Helakorpi S, Patja K, Prattala R, et al. Health behaviour and health among the Finnish adult population. Finnish National Health Institute, 2005

23. Ali SM, Chaix B, Merlo J, et al. Gender differences in daily smoking prevalence in different age strata: a population-based study in southern Sweden. Scand J Public Health 2009;37:146-52.

24. Giovino GA, Mirza SA, Samet JM, et al. Tobacco use in 3 billion individuals from 16 countries: an analysis of nationally representative cross-sectional household surveys. Lancet 2012;380:668-79.

25. Kentala J, Utriainen $\mathrm{P}$, Pahkala $\mathrm{K}$, et al. Can brief intervention through community dental care have an effect on adolescent smoking? Prev Med 1999;29:108-9.

26. Saari AJ, Kentala J, Mattila KJ. Long-term effectiveness of adolescent brief tobacco intervention: a follow-up study. BMC Res Notes 2012:5:101.

27. Klein EG, Forster JL, Erickson DJ. Longitudinal predictors of stopping smoking in young adulthood. $J$ Adolesc Health 2013;53:363-7.

28. Broms U, Koskenvuo K, Sillanmäki LH, et al. Best friend's and family members' smoking habits and parental divorce during childhood are associated with smoking in adulthood. Nordic Stud Alcohol Drugs 2012;29:441-52.

29. Baines E, Blatchford P. Sex differences in the structure and stability of children's playground social networks and their overlap with friendship relations. Br J Dev Psychol 2009;27:743-60.

30. Coambs RB, Li S, Kozlowski LT. Age interacts with heaviness of smoking in predicting success in cessation of smoking. $A m \mathrm{~J}$ Epidemiol 1992;135:240-6. 